\title{
Assessment of Viral and Atypical Bacterial Agents Using Polymerase Chain Reaction in Patients Presenting with Signs of Acute Respiratory Tract Infection
}

\author{
E Ünver ${ }^{1}, \mathrm{~F}$ Karakeçili², A Çıkman ${ }^{3}$
}

\begin{abstract}
Objective: To assess viral and atypical bacterial agents using polymerase chain reaction in patients presenting with signs of acute respiratory tract infection (RTI) to Erzincan Mengucek Gazi Education and Research Hospital, Turkey.

Methods: Viral and atypical bacterial agents were explored in patients presenting with RTI between February 1 and June 1, 2017. Genomic isolation was performed using a SolMag ${ }^{\circledR} 2$ fully-automated nucleic acid isolation system and SolMag ${ }^{\circledR}$ Virus Nucleic Acid Isolation Kit. Amplifications were performed using a SmartCycler-II thermocycler (Cepheid) device in accordance with the instructions provided by the manufacturer.

Results: Of the 120 patients, 44 (36.6\%) were found to have at least one agent. Polymerase chain reaction detected influenza viruses in 28 patients, respiratory syncytial virus in seven, cytomegalovirus (CMV) in six, Herpes simplex virus 1 (HSVI) in two, Chlamydophila pneumonia in two, Human Herpesvirus 6 in one, and Herpes simplex virus 2 in one. Also, coexistent HSV1 and CMV positivity was found in two cases. One patient had positivity in both influenza A and CMV. Among atypical bacterial agents, only two patients were found to have Chlamydophila pneumonia. There was at least one comorbid condition in 48 patients (40\%). Of these subjects in whom an agent could be identified, 21 were found to have co-morbidity, while 23 were free of comorbid conditions. Antibiotherapy had been started in 109 (90.8\%) of the patients after initial assessment. Sixty-four patients were admitted, and two patients died. Conclusion: Polymerase chain reaction allowed rapid detection of agents responsible for acute RTIs. We believe that this technique may contribute to appropriate use of antibiotics in patients diagnosed with atypical bacterial infection and may prevent unnecessary antibiotherapy in infections caused by viral agents.
\end{abstract}

Keywords: Acute respiratory tract infection, atypical bacteria, polymerase chain reaction, respiratory viruses

From: ${ }^{1}$ Department of Chest Diseases, Faculty of Medicine, Erzincan University, Erzincan, Turkey, ${ }^{2}$ Department of Infectious Diseases and Clinical Microbiology, Faculty of Medicine, Erzincan University, Erzincan, Turkey and ${ }^{3}$ Department of Medical Microbiology, Faculty of Medicine, Erzincan University, Erzincan, Turkey.
Correspondence: Dr E Ünver, Department of Chest Diseases, Faculty of Medicine, Erzincan University, Erzincan, Turkey. Email: ethemunver@hotmail.com 


\title{
Evaluación de agentes bacterianos atípicos y agentes virales utilizando la reacción en cadena de la polimerasa en pacientes que se presentan con signos de infección aguda de las vías respiratorias
}

\author{
E Ünver ${ }^{1}$, F Karakeçili², A Çıkman ${ }^{3}$
}

\begin{abstract}
RESUMEN
Objetivo: Evaluar los agentes bacterianos atípicos y los agentes virales utilizando la reacción en cadena de la polimerasa en pacientes que acuden con signos de infección aguda de las vías respiratorias (IVR) al Hospital de Docencia e Investigación Erzincan Mengucek Gazi, Turquía.

Métodos: Se exploraron agentes bacterianos atípicos y agentes virales en pacientes que acudieron con IVR entre el 1 de febrero y 1 de junio de 2017. El aislamiento genómico se realizó con un sistema SolMag ${ }^{\circledR} 12$ de aislamiento de ácido nucleico totalmente automatizado y un Kit SolMag ${ }^{\mathbb{B}}$ de aislamiento de ácido nucleico viral. Las amplificaciones se realizaron utilizando un aparato termociclador SmartCycler-II (Cepheid) de acuerdo con las instrucciones proporcionadas por el fabricante.

Resultados: De los 120 pacientes, se determinó que 44 (36.6\%) tenían al menos un agente. La reacción en cadena de la polimerasa detectó virus de la influenza en 28 pacientes, virus sincitial respiratorio en siete, citomegalovirus (CMV) en seis, herpes virus simplex 1 (HSV1) en dos, Chlamydophila pneumoniae en dos, herpes virus humano 6 en uno, y herpes virus simplex 2 en uno. Por otro lado, se halló positividad coexistente de HSV1 y CMV en dos casos. Un paciente tuvo positividad tanto para la influenza A como para CMV. Entre los agentes bacterianos atípicos, se halló sólo dos pacientes con Chlamydophila pneumonia. Hubo al menos una condición comórbida en 48 pacientes (40\%). De estos sujetos en los que se podía identificar un agente, se halló que 21 tenían comorbilidad, mientras que 23 estaban libres de condiciones comórbidas. La antibioterapia habia comenzado en 109 (90.8\%) de los pacientes después de la evaluación inicial. Sesenta y cuatro pacientes fueron ingresados, y dos pacientes murieron. Conclusión: La reacción en cadena de la polimerasa permitió la rápida de detección de agentes responsables de IVR aguda. Creemos que esta técnica puede contribuir al uso apropiado de antibióticos en pacientes diagnosticados con infección bacteriana atípica normal y puede evitar antibioterapias innecesarias en infecciones causadas por los agentes virales.
\end{abstract}

Palabras clave: Infección aguda de las vías respiratorias, bacterias atípicas, reacción en cadena de la polimerasa, virus respiratorios

West Indian Med J 2018; 67 (4): 299

\section{INTRODUCTION}

'Acute respiratory tract infections' (RTIs) is an umbrella term encompassing acute upper RTIs (URTIs) (such as acute tonsillitis, rhinitis, sinusitis, pharyngitis, tonsillopharyngitis and diphtheria) and lower RTIs (LRTIs) (such as acute laryngitis, acute bronchitis, acute bronchiolitis and pneumonia) $(1,2)$. Respiratory tract infections are among the four major causes of morbidity and mortality in adults and children (3). Recurrent RTIs may lead to community-based and healthcare-associated infections, posing a significant public health problem. Respiratory tract infections may be caused by bacteria, viruses and parasites (4-6), although viruses are thought to be responsible for the majority (approximately $20-60 \%$ ) of these infections (7-9). Viral agents that are mostly involved include the respiratory syncytial virus (RSV), influenza A/B, rhinovirus, adenovirus, EppsteinBarr virus (EBV) and cytomegalovirus (CMV), while the most common atypical agents are Streptococcus pneumoniae, Haemophilus influenzae, Mycoplasma 
pneumoniae (M pneumoniae), Chlamydophila pneumoniae (C pneumoniae), and Legionella pneumophila (10-13). Also, several Herpes viruses such as Herpes simplex virus 1 (HSV1), Herpes simplex virus 2 (HSV2) and Human Herpesvirus 6 (HHV6) have been reported to be potentially associated with acute RTIs $(14,15)$.

In patients with clinical, laboratory and radiological signs of acute RTI, identification of the microbiological agents responsible for the infection will prevent unnecessary use of antibiotics. Although detection with cultures represents the gold standard, this approach is associated with a number of drawbacks including prolonged testing procedure as well as the inability to grow some of the micro-organisms. In contrast, polymerase chain reaction (PCR) may play a significant diagnostic role based on its ability to provide prompt results and its low cost (16). This study aimed to describe the distribution of microbiological agents in nasopharyngeal swab samples in patients attending Erzincan Mengucek Gazi Education and Research Hospital, Turkey, with signs and symptoms of acute RTI.

\section{SUBJECTS AND METHODS}

\section{Patients}

Patients attending our hospital with signs and symptoms of acute RTI (such as cough, high fever, throat-headchest pain, nasal discharge and/or obstruction, fatigue, tiredness, and shortness of breath) between February 1 and June 1, 2017 were included. Accordingly, a total of 120 patients with either acute URTI (including acute tonsillitis, rhinitis, sinusitis, laryngitis, pharyngitis and tonsillo-pharyngitis) or LRTI (such as acute bronchitis, acute bronchiolitis and pneumonia) were studied. Polymerase chain reaction for $M$ pneumonia, $C$ pneumonia and Legionella spp was performed in 96 patients, PCR for HSV1, HSV2, varicella-zoster virus (VZV), CMV, EBV and HHV6 was performed in 74 patients, and PCR for influenza A/B and RSV was performed in 109 patients.

Age, gender, physical complaints, and physical examination findings were recorded in all patients. Based on clinical pre-diagnosis, a number of diagnostic tests were performed, such as complete blood count, electrolytes, C-reactive protein (CRP), aspartate aminotransferase, alanine aminotransferase, lactate dehydrogenase, creatinine phosphokinase, plasma creatinine, blood cultures, postero-anterior chest X-ray, and respiratory function tests. Also, nasopharyngeal swab samples were obtained from all patients for isolation of the causative agent. Nasopharyngeal samples obtained using special swabs were placed in viral transport medium (HiViral Transport Kit, India) and were transported to the clinical microbiology laboratory in appropriate transport containers without delay in keeping with the cold-chain and biosafety principles.

\section{Laboratory diagnosis}

After the samples were transferred to the laboratory, tests were carried out for the identification of causative organisms in accordance with appropriate procedures. The tested organisms included those responsible for atypical pneumonia (such as M pneumonia, C pneumonia and Legionella spp), Herpes viruses (such as HSV1, HSV2, VZV, EBV, CMV, HHV6) and influenza viruses (such as influenza virus $\mathrm{A} / \mathrm{B}$ and RSV). The genomic isolation was performed using a fully-automated nucleic acid isolation system (SolMag ${ }^{\circledR} 12$, Taiwan) and a Solmag ${ }^{\circledR}$ Virus Nucleic Acid Isolation Kit (Taiwan). In this method, initially, $1200 \mu \mathrm{L}$ of ribonucleic acid (RNA) carrier was diluted with water. Then, $20 \mu \mathrm{L}$ of carrier was pipetted into the sample tube, and $480 \mu \mathrm{L}$ of sample was added. The reactive cartridges and pipette tips were placed respectively. The samples were placed in the ' $S$ ' plate in the sample rack, elution tubes in ' $E$ ' plate, and internal control in 'IC' plate. Then, in accordance with the manufacturer's instructions, the tests were carried out. After the nucleic acid purification protocol lasting 45 minutes, $100 \mu \mathrm{L}$ of nucleic acid (DNA or RNA) was isolated.

The following were used in clinical samples: RealCycler FLURSV kit allowing simultaneous realtime quantification with PCR for influenza $\mathrm{A} / \mathrm{B}$ and RSV RNA, RealCycler HERPLX kit allowing real-time quantification with PCR for Herpes viruses (HSV1, HSV2, VZV, EBV, CMV and HHV6), and RealCycler MYCHLE diagnostic kit allowing real-time simultaneous quantification with PCR for $M$ pneumoniae, $C$ pneumonia and Legionella spp. In these diagnostic kits, the following conservative gene regions were targeted: $M_{1}$ and $M_{2}$ genes for influenza $A / B$, fusion protein gene for RSV, US6 gene for HSV1, DNA polymerase gene for HSV2, single-stranded DNA-binding protein (also known as ORF29) for VZV, LMP1 gene for EBV, glycoprotein B gene for CMV, U67 gene for HHV6, P1 gene for $M$ pneumonia, DNA-directed RNA polymerase subunit beta gene for $C$ pneumonia, and $23 \mathrm{~S}$ $5 \mathrm{~S}$ ribosomal gene for Legionella spp. Amplifications were assessed using a SmartCycler II thermocycler (Cepheid). A $23 \mu \mathrm{L}$ master mix was prepared, and a total of $25 \mu \mathrm{L}$ total reaction volume was obtained after 
addition of $2 \mu \mathrm{L}$ of DNA samples. The data were analysed using the SmartCycler system software with absolute quantification method.

\section{Statistical analyses}

SPSS 18.0 software pack was used for data analyses. Descriptive statistics was used for all variables. The normal distribution of the variables was tested using Kolmogorov Smirnov test.

\section{RESULTS}

A total of 120 patients (66 males $/ 55 \%$ and 54 females/45\%) aged between 0 and 87 years (mean age: 38.18 years) were included in the study. Of these patients, 71 had URTI (acute tonsillitis, rhinitis, sinusitis, pharyngitis, tonsillo-pharyngitis etc) and 49 had LRTI (acute laryngitis, acute bronchitis, acute bronchiolitis, pneumonia etc).

The most frequent signs and symptoms at the time of presentation included cough (85.0\%), high fever $(83.3 \%)$, nasal discharge $(56.6 \%)$ and shortness of breath $(50.8 \%)$, while the most common laboratory findings were elevated CRP (59.1\%), leukocytosis (25.0\%), anaemia (19.1\%), thrombocytopaenia (17.5\%) and leukopaenia (11.6\%). A postero-anterior chest X-ray radiograph was obtained in 89 patients at the initial presentation, with 49 of these showing radiological abnormality. Table 1 shows the symptoms/signs and laboratory findings.

Of the 120 participants, $44(36.6 \%)$ had at least one causative agent. However, the total number of isolated

Table 1: Symptoms and laboratory findings in patients

\begin{tabular}{lr}
\hline & $\begin{array}{c}\text { Number of patients } \\
\text { (\%) }\end{array}$ \\
\hline Symptoms & $102(85)$ \\
Cough & $100(83.3)$ \\
High fever & $68(56.6)$ \\
Nasal discharge & $61(50.8)$ \\
Shortness of breath & $38(31.6)$ \\
Weakness & $25(20.8)$ \\
Headache & $23(19.1)$ \\
Throat pain & \\
Laboratory findings & $71(59.1)$ \\
Increased C-reactive protein $(>0.8 \mathrm{mg} / \mathrm{dL})$ & $30(25)$ \\
Leukocytosis $\left(>10.000 / \mathrm{mm}^{3}\right)$ & $23(19.1)$ \\
Anaemia $(<12 \mathrm{mg} / \mathrm{dL})$ & $21(17.5)$ \\
Thrombocytopenia $\left(<150000 / \mathrm{mm}^{3}\right)$ & $14(11.6)$ \\
Leukopaenia $\left(<4000 / \mathrm{mm}^{3}\right)$ & $14(11.6)$ \\
Increased aspartate aminotransferase $(>40 \mathrm{U} / \mathrm{L})$ & $11(9.1)$ \\
Increased alanine aminotransferase $(>40 \mathrm{U} / \mathrm{L})$ & \\
\hline
\end{tabular}

agents was 47. Polymerase chain reaction was able to detect influenza viruses in 28 participants, RSV in seven, CMV in six, HSV1 in two, HHV6 in one, and HSV2 in one. The influenza virus subtypes included 23 cases with influenza B and five cases with influenza A. Furthermore, two patients had co-existence of HSV1 and CMV. One patient had co-occurrence of influenza A and CMV. The distribution of atypical agents showed $C$ pneumonia in only two patients, who were admitted in April and May, respectively. Similarly, most influenza $\mathrm{B}$ cases were diagnosed between the end of March and beginning of May. Also, those five patients with influenza A were diagnosed at the beginning of March. The other causative agents displayed no specific pattern of distribution. In 76 participants, none of the agents tested could be identified.

Forty-eight patients $(40 \%)$ had at least one co-morbidity. Twenty-one of the patients with an identified pathogen had comorbid conditions, while 23 had no co-morbidity. Three of six patients with CMV positivity had comorbid conditions (one asthma, one benign prostatic hyperplasia (BPH) and diabetes mellitus (DM), and one atrial fibrillation). Among patients with $C$ pneumonia, there was one case with asthma. Three of the five patients with influenza A positivity had co-morbidity (two asthma, one chronic obstructive pulmonary disease (COPD) and lung cancer), while 18 of 23 patients with influenza B positivity had co-morbidity (asthma, hypertension, congestive heart failure (CHF), DM). Of the patients with HSV1 positivity, one had BPH and DM, and the patient with HHV6 positivity had vitamin deficiency. None of the seven RSV-positive patients had co-morbidity. Accordingly, asthma, COPD and vitamin deficiency were the most common conditions in patients,

Table 2: Isolated agents in patients with acute respiratory tract infection

\begin{tabular}{|c|c|c|c|c|}
\hline \multirow[t]{2}{*}{ Isolated agents } & \multicolumn{2}{|c|}{$\begin{array}{l}\text { Upper respiratory } \\
\text { tract infection }\end{array}$} & \multicolumn{2}{|c|}{$\begin{array}{l}\text { Lower respiratory } \\
\text { tract infection }\end{array}$} \\
\hline & Positive & Negative & Positive & Negative \\
\hline Influenza A & $4 *$ & 105 & 1 & 108 \\
\hline Influenza B & 11 & 98 & 12 & 97 \\
\hline Herpes simplex virus 1 & 0 & 74 & $2 * *$ & 72 \\
\hline Herpes simplex virus 2 & 1 & 73 & 0 & 74 \\
\hline Cytomegalovirus & $4 *$ & 70 & $2 * *$ & 72 \\
\hline Human Herpesvirus 6 & 0 & 74 & 1 & 73 \\
\hline Respiratory syncytial virus & 7 & 102 & 0 & 109 \\
\hline Atypical agents & 0 & 96 & 2 & 94 \\
\hline Total positive & 27 & & 20 & \\
\hline
\end{tabular}

* Influenza A in combination with cytomegalovirus was present in one patient. ** Herpes simplex virus 1 in combination with cytomegalovirus was present in two patients. 
in whom a causative agent was found. Also iron deficiency, lung cancer, hypertension, CHF, BPH and DM occurred at a lower frequency.

Demographic characteristics of the patients in whom an identified causative agent was found were also examined. Accordingly, there were three male and three female CMV-positive patients who were between 49 and 82 years of age; one male and one female patient with $C$ pneumonia aged 58 and 62 years, respectively; four female and one male patients with influenza A positivity who were between 39 and 64 years of age; nine male and 14 female patients with influenza B aged between 15 and 76 years; two male patients with HSV1-positivity aged 63 and 82 years, respectively; and one male patient with HHV6 positivity who was 62 years old.

Of the patients with URTI, 36.6\% (26/71) had at least one causative agent. Influenza B, RSV, influenza A, CMV, HSV2, influenza A with CMV were detected in $11,7,3,3,1$ and 1 of these 26 patients, respectively. Among patients with LRTI, 36.7\% (18/49) had at least one causative agent. Influenza B, C pneumoniae, influenza A, HHV6, HSV1 with CMV were detected in 12, $2,1,1$ and 2 of these 18 patients, respectively (Table 2 ).

Antibiotherapy was initiated in 109 (90.8\%) of our patients after initial assessment, and the necessity of antibiotic therapy was re-assessed based on PCR results and clinical examination findings. Sixty-four patients were admitted, while 56 were treated and followed up as outpatients. Two of the admitted patients died, while others were discharged with cure.

\section{DISCUSSION}

Respiratory tract infections represent a major cause of infectious diseases globally and are associated with significant societal economic burden due to cost of treatment, hospital admission, and absenteeism from work and school. Acute RTIs are associated with significant morbidity and mortality, representing a major public health problem, particularly in developing countries. Clinical manifestations alone are generally inadequate to identify the causative micro-organism. Most of the infections involving the upper respiratory tract are known to be caused by viral agents. Viral RTIs are two to three times more common in children than adults, although at least 20 bacterial and viral agents are known to cause LRTIs. Therefore, proper diagnostic tests are required for accurate identification of the causative agents $(9,17-19)$.

In this study which involved a group of patients who attended our facility with signs/symptoms of acute RTI during a four-month period, the causative agents were examined using real-time PCR to determine their distribution. Of our participants, $36.6 \%$ had at least one causative agent, and most of these agents were viral in nature. In previous studies, the reported viral positivity rates in RTIs ranged between $45 \%$ (in one study involving patients with URTI) and 15-56\% (in community-acquired pneumonia) $(20,21)$. In the current study, most cases (42 patients) were caused by respiratory viruses, with atypical bacterial agents being responsible for only a minority (two patients). Similarly, viral agents were more common in patients with URTI.

The distribution pattern of aetiological agents in RTIs exhibits a certain degree of variation based on season, age, ethnicity, geography and underlying conditions. Although RTIs display some annual variability, the peak incidence generally occurs during winter months. Viral agents are more common during winter months, as opposed to more common occurrence of atypical bacterial agents during summer and autumn $(19,22)$. Since our study was undertaken in winter-spring months, viral agents were more common, and atypical agents were infrequent. The two patients in whom atypical bacterial agents were identified attended our hospital at the end of spring or beginning of summer.

Although viral agents are associated with URTIs more commonly, they may also lead to LRTIs in the elderly, newborns, immune-compromised individuals and patients with comorbid conditions. While influenza and coronaviruses are more prominent in LRTIs, RSV was found to be more common in URTIs $(23,24)$. In 21 of our patients in whom a causative agent could be identified, there was a comorbid condition, while 23 were free of co-morbidity. Influenza A/B viruses are particularly associated with LRTIs, and they were more common in patients with co-morbidities such as asthma or COPD. Also, none of our patients with RSV-associated RTIs had comorbid conditions. Sixty-four patients, most of whom had co-morbidities, required hospital admission, while 56 were treated and followed up as outpatients. Two of the patients who were subsequently transferred to the intensive care unit died, while the remaining patients were discharged with cure.

Although viruses represent the most common cause of RTIs, antibiotics are frequently prescribed due to the difficulties associated with the identification of the causative agents. Differentiation between infections of viral and bacterial aetiology based on clinical and laboratory findings is not always feasible, leading to unnecessary use of antibiotics in many patients with a 
consequent increase in treatment costs, antibiotic resistance, and side-effects of antibiotic treatment. Although 'microbiological cultures' represent the gold standard in microbiological diagnosis, they are undermined by a number of disadvantages including the inability to invariably identify the causative agent as well as their time-consuming nature. On the other hand, PCR tests are based on the principle of showing the presence of nucleic acids of micro-organisms and require minimal time. Polymerase chain reaction is a molecular method with high sensitivity in respiratory samples $(25,26)$. In all age groups, PCR was able to provide quick results, allowing re-assessment of antibiotic use in patients with a viral agent identified. Also, it allowed the early initiation of appropriate antiviral treatment, especially in patients with influenza $\mathrm{A} / \mathrm{B}$ infection. Also, in two patients with atypical bacterial agents, appropriate antibiotic treatment could be started rapidly.

The real-time PCR methodology based on the use of respiratory samples also allowed the identification of different viruses simultaneously. Identification, surveillance, and seasonal distribution of viruses responsible for RTIs carry significant clinical importance, since it assists in detection of viruses with a potential to cause epidemics and pandemics.

In conclusion, clinical findings generally fail to identify the causative micro-organisms in this patient population. Rapid identification of causative agents with PCR will provide valuable information for the clinician who treats patients with similar clinical manifestations. Polymerase chain reaction allows quick identification of bacterial and viral causative agents. This will also assist in the choice of appropriate antibiotics for patients with atypical bacterial infections, while reducing unnecessary antibiotic use in viral infections.

\section{REFERENCES}

1. Topaloğlu N, Yıldırım Ş, Tekin M, Uludağ A, Özgen K. Alternative treatment applications in children with respiratory tract infections in the west of Turkey. J Curr Pediatr 2013; 11: 23-6.

2. Örün E, Yalçın SS, Yurdakök K. Physician approach to children with acute respiratory tract infections according to WHO criteria. Çocuk Sağlığı Hast Derg 2007; 50: 16-24.

3. Çiçek C, Arslan A, Karakuş HS, Yalaz M, Saz EU, Pullukçu H et al. Prevalence and seasonal distribution of respiratory viruses in patients with acute respiratory tract infections, 2002-2014. Microbiol Bul 2015; 49: 188-200.

4. Esposito S, Principi N. Impact of nasopharyngeal microbiota on the development of respiratory diseases. Eur J Clin Microbiol Infect Dis 2018; 37: 1-7.
5. Peneş NO, Muntean AA, Moisoiu A, Muntean MM, Chirca A, Bogdan MA et al. An overview of resistance profiles ESKAPE pathogens from 2010-2015 in a tertiary respiratory center in Romania. Rom J Morphol Embryol 2017; 58: 909-22.

6. Eschapasse E, Hussenet C, Bergeron A, Lebeaux D. Respiratory infections caused by slow-growing bacteria: Nocardia, Actinomyces, Rhodococcus. Rev Mal Respir 2017; 34: 661-71.

7. World Health Organization. World Health Statistics 2011. WHO, Geneva. Available at: www.who.int/whosis/whostat/2011/en.

8. Zumla A. Killer respiratory tract infections: time to turn the tide. Curr Opin Pulm Med 2012; 18: 173-4.

9. Tregoning JS, Schwarze J. Respiratory viral infections in infants: causes, clinical symptoms, virology, and immunology. Clin Microbiol Rev 2010; 23: 74-98.

10. Petrova VN, Russell CA. The evolution of seasonal influenza viruses. Nat Rev Microbiol 2018; 16: 47-60.

11. Sologub TV, Tsvetkov VV. Kagocel in the therapy of influenza and acute respiratory viral infections: data analysis and systematization from the results of preclinical and clinical trials. Ter Arkh 2017; 89: 113-9.

12. Head BM, Trajtman A, Rueda ZV, Vélez L, Keynan Y. Atypical bacterial pneumonia in the HIV-infected population. Pneumonia (Nathan) 2017; 25: $9-12$.

13. Bergenfelz C, Hakansson AP. Streptococcus pneumoniae otitis media pathogenesis and how it informs our understanding of vaccine strategies. Curr Otorhinolaryngol Rep 2017; 5: 115-24.

14. Luyt CE, Bréchot N, Chastre J. What role do viruses play in nosocomial pneumonia? Curr Opin Infect Dis 2014; 27: 194-9.

15. Cone RW. Human herpesvirus 6 as a possible cause of pneumonia. Semin Respir Infect 1995; 10: 254-8.

16. Ecemiş T, Yılmaz Ö, Şanlıdağ T, AkçalI S, Yüksel H. Investigation of viral agents by multiplex PCR in children with symptoms of upper respiratory tract infection. Behçet Uz Çocuk Hast Derg 2012; 2: 1-5.

17. Kesson AM. Respiratory virus infections. Paediatr Respir Rev 2007; 8: 240-8.

18. Templeton KE. Why diagnose respiratory viral infection? J ClinVirol 2007; 40(Suppl 1): 2-4.

19. Bayrakdar F, Altaş AB, Gülay Korukluoğlu G. Seasonal distribution of the respiratory tract viruses in Turkey between 2009 and 2012. Türk Mikrobiyol Cem Derg 2013; 43: 56-66.

20. Leekha S, Irish CL, Schneider SK, Fernholz EC, Espy MJ, Cunningham $\mathrm{SA}$ et al. Viral detection using a multiplex polymerase chain reactionbased assay in outpatients with upper respiratory infection. Diagn Microbiol Infect Dis 2013; 75: 169-73.

21. Ruuskanen O, Lahti E, Jennings LC, Murdoch DR. Viral pneumonia. Lancet 2011; 377: 1264-75.

22. Kaygusuz S, Köksal İ, Kostakoğlu U, Kaya S, Bayraktar Ö. Investigation of atypical agents in respiratory tract infections. Flora 2001; 6: 225-30.

23. Corman VM, Eckerle I, Bleicker T, Zaki A, Landt O, Eschbach-Bludau $\mathrm{M}$ et al. Detection of a novel human coronavirus by real-time reversetranscription polymerase chain reaction. Euro Surveill 2012; 17: pii 20285.

24. Hirsch HH, Martino R, Ward KN, Boeckh M, Einsele H, Ljungman P. Fourth European Conference on Infections in Leukaemia (ECIL-4): guidelines for diagnosis and treatment of human respiratory syncytial virus, parainfluenza virus, metapneumovirus, rhinovirus, and coronavirus. Clin Infect Dis 2013; 56: 258-66.

25. Sancaklı Ö, Yenigün A, Kırdar S. Results of polymerase chain reaction in nasopharyngeal swab specimens of patients with lower respiratory tract infection. J Pediatr Inf 2012; 6: 84-9.

26. Gharabaghi F, Hawan A, Drews SJ, Richardson SE. Evaluation of multiple commercial molecular and conventional diagnostic assays for the detection of respiratory viruses in children. Clin Microbil Infect 2011; 17: 1900-6. 